\title{
Effect of Soy Flour Supplementation on the Quality and Shelf Life of Gulabjamuns
}

\author{
A. K. Singh ${ }^{1}$, Dattatreya M. Kadam ${ }^{2, *}$, Mili Saxena ${ }^{3}$, R. P. Singh ${ }^{4}$ \\ ${ }^{1}$ Dept. of Processing and Food Engineering, PAU, Ludhiana \\ ${ }^{2}$ Central Institute of Post-Harvest Engineering and Technology, PO: PAU, Ludhiana \\ ${ }^{3}$ GNEC, Ludhiana \\ ${ }^{4}$ Dept. of Chemistry, GNEC, Ludhiana
}

\begin{abstract}
An attempt was made to improve the nutritional quality of desert 'Gulabjamun' with supplementation of protein rich defatted soyflour to replace wheat-flour of control recipe in the levels of 3.33\%, $6.66 \%$ and $9.99 \%$ and control. The data were analysed using the procedure of two-way ANOVA using GLM of SPSS. Protein and fat content of Gulabjamuns decreased with increase in the storage periods irrespective of soyflour supplementation in Gulabjamuns and storage condition. The shelf life of Gulabjamuns at ambient $\left(26.60^{\circ} \mathrm{C}\right.$ to $\left.36.25^{\circ} \mathrm{C}\right)$ and refrigeration $\left(4\right.$ to $\left.7^{\circ} \mathrm{C}\right)$ conditions were varied from 8 to 10 days and 10 to 14 days, respectively. Decrease of protein and fat content (\%) during storage varied from 18.29 to $30.37 \%$ and 31.02 to $34.44 \%$ in ambient and 19.98 to $30.93 \%$ and 19.27 to $36.21 \%$ in refrigerator condition, respectively. Textural behaviour of stored Gulabjamuns was increased with increase in the soyflour supplementation, storage period and supplementation of $6.66 \%$ soyflour is best.
\end{abstract}

Keywords Gulabjamun, Fortification, Nutritional Quality, Soy Flour, Shelf Life, Textural Behaviour

\section{Introduction}

Cereals are the major source of protein in Indian diet, which has an inferior quality of protein as compared to other vegetable and animal proteins. Soybean is one of the nature's wonderful nutritional gifts. It is one of the very few plants that provide a complete protein with minimum saturated fat. Regular consumption of soybean helps to prevent cancer, reduce cholesterol level, combating osteoporosis and menopause regulation. Soybeans contain all the three essential macro nutrients required for good nutrition, complete protein $(40 \%)$, carbohydrate $(18 \%)$, fat $(18 \%)$ and moisture (9\%) apart from vitamins and minerals $(5 \%)$, including folic acid, calcium, potassium and iron (National Soybean Research Laboratory, 2008; Singh et. al., 2009). Soybean protein also provides all the nine essential amino acids in the amounts needed for human health. The amino acid pattern of soy protein is virtually equivalent in quality to that of meat, milk and egg protein. Soybeans are most valued nutritionally for their unsaturated fatty acids, protein and fiber content $(10 \%)$. The recent nutritional survey conducted by Food and Nutrition Board of Govt. of India suggests that, India is facing protein calorie malnutrition; intake of pulses and availability of oil is less than

* Corresponding author:

kadam1k@gmail.com (Dattatreya M. Kadam)

Published online at http://journal.sapub.org/food

Copyright (C) 2011 Scientific \& Academic Publishing. All Rights Reserved recommended Daily Allowance (RDA). Fortification of soy flour with cereals will improve the protein quality.

Mishra and Mukherjee (1992) studied the storage stability of full fat soy flour (FFSF) and soy-wheat flour blend at different temperatures and relative humidities and found that thermally processed and prepared FFSF could be stored safely at ambient temperature for more than 4 months either alone or in combination with wheat flour. Different types of protein rich products can be prepared from soybean such as thin flakes, oil, soy flour, soy concentrates, soy meat, soy isolates, cheese, soymilk, infant formula, non-dairy frozen desserts and coffee whiteners.

Anna et al. (2005) studied the effect of soy fortification $(20 \%)$ on the development of aroma compounds, dough acidity and growth of the predominant microorganisms in Ghanaian maize dough fermented spontaneously over a period of $72 \mathrm{~h}$ and found that total concentration of esters in soy-fortified dough decreased after $72 \mathrm{~h}$ while levels in the unfortified dough increased. Twenty-three compounds were perceived to be contributing to the typical aroma of soy-fortified maize dough. Addo et al. (1996) studied the effects of indigenous fermentation and soy fortification on the protein quality and carbohydrate digestibility of a traditional Ghanaian corn meal. Addition of defatted soybean flour to the meal significantly improved protein quality and DNFB-available lysine. Indigenous fermentation also caused an increase in the in vitro carbohydrate digestibility of the non-fortified corn meal. Addition of whole soybeans to maize before milling and fermentation reduced the fer- 
mentation time by $60 \%$ while increasing the protein content by $24 \%$ and $70 \%$ respectively for $10 \%$ and $20 \%$ levels of fortification and found a significant improvement was also achieved in the amino acids pattern of the fortified dough (Plahar et al., 1997).

Highly nutritious, soy-based baby foods have been prepared. Baby foods prepared from soymilk with corn, soymilk with rice and soymilk with wheat, contain protein 28.5 , 25.0 , and $26.0 \%$, fat $9.50,9.00$ and $10.0 \%$ and carbohydrates $54.9,58.5$ and $56.0 \%$, respectively. Protein efficiency ratios of the three formulations were comparable with casein. The products prepared were of cream-white colour, possessed good taste and fluffy texture and contained all nutrients known to be essential for babies and preschool children (Wadud et al., 2004).

Achi (1999) used pretreated soy flour to replace 10, 20, 30 and $40 \%$ of fermented yam flour as a protein supplement. Protein content of the yam-soy mixture increased from $3.5 \%$ in the control to $19.7 \%$ for $40 \%$ soy fortification. Water binding capacity increased from $212.6 \mathrm{~g} / 100 \mathrm{~g}$ for the yam flour control to $257.3 \mathrm{~g} / 100 \mathrm{~g}$ for the blend with $40 \%$ soy flour. However, swelling capacity and solubility were adversely affected with increased soy flour addition as dough became sticky and soft.

In India, different types of sweets/ deserts are consumed and Gulabjamun is the one of the most important sweet consumed throughout the country. Gulabjamun is a popular and favorite Indian sweet dish/ desserts comprised of fried milk balls of golden brown colour in a sweet syrup flavoured with cardamom seeds and rosewater or saffron which is served warm or cool. Saxena et al. (1996) studied the soy flour (SF) - Gulabjamun premixes and ready-to-serve SF-Gulabjamun prepared from admixture of soy flour and milk solids. Control and SF-Gulabjamuns showed significant differences $(\mathrm{p}<0.05)$ in all constituents except sucrose. Gulabjamuns with $40 \%$ soy flour substitution of whole milk powder was rated the best among all types of SF- Gulabjamuns in flavour and overall acceptability.

The most serious constraint for shelf life enhancement is the activity of microorganisms. During recent years exhaustive efforts were made for an improvement in quality retention of products by altering processing strategy and / or pre-treatment (Rahman and Perera, 1999). Processing and subsequent storage causes variation in food characteristics. Environmental parameters such as temperature, air humidity or light can trigger reaction mechanisms that lead to the degradation of some quality aspects of the food. During storage, one or more food characteristics can reach an undesirable state, and as a consequence the consumer may reject the product or it can even cause detrimental health. At this moment, it is considered that the food has reached the end of its shelf life (Singh et al., 1989).

An attempt was made to study the effect of soy flour mix supplementation on the quality, storability and storage condition of Gulabjamuns as comparison to commercially available Gulabjamuns.

\section{Materials and Methods}

The experiment presented in this section was carried out in the Department of Processing and Food Engineering, Punjab Agricultural University, Ludhiana to study the effect of soy flour supplementation on the quality and shelf life of Gulabjamuns as compare to commercially available $\mathrm{Gu}$ labjamuns and resultant changes in physico-chemical characteristics of Gulabjamuns at ambient and refrigerated conditions. During storage studies ambient temperature varied from $26.60^{\circ} \mathrm{C}$ to $36.25^{\circ} \mathrm{C}$ with mean temperature of $31.40^{\circ} \mathrm{C}$ and relative humidity varied from $54.0 \%$ to $74.5 \%$ with mean of $64.0 \%$ whereas domestic refrigerator temperature was maintained between 4 and $7^{\circ} \mathrm{C}$. The Gulabjamun preparation process was followed as per method given by Rangi et al. (1985) and same is reported elsewhere (Singh et. al., 2009).

\section{Sample Preparation}

The raw materials for making Gulabjamun premix were procured from the local market. The control sample preparation premix was consists of khoa $(66.66 \%)$, paneer $(16.6 \%)$, wheat flour $(13.3 \%)$, semolina $(2.66 \%)$, baking powder $(0.16 \%)$ and refined oil $(0.62 \%)$. Soy flour was supplemented to replace wheat flour in control recipe in the levels of $3.33 \%$ (T2), $6.66 \%$ (T3) and 9.99\% (T4) to prepare three different soy flour composition Gulabjamuns and one control (T1) sample (without soy flour). All the ingredients like khoa, paneer, wheat flour, soy flour, semolina, refined oil and baking powder were weighed and mixed thoroughly in small quantity of water to make dough and thereafter small spherical shape balls weighing $10 \mathrm{~g}$ each were made manually (Singh et. al., 2009). The premix dough was converted into balls of uniform spherical shape (10 g each) and deep fat fried to get a light brown coloured surface using the electrical fryer at the temperature of $130^{\circ} \mathrm{C}$ for 15 minutes (Rangi et al., 1985) and fried samples were taken out of frying pan to remove excess surface fat before dipping it in sugar syrup.

\section{Preparation of Sugar Syrup}

Sugar of $250 \mathrm{~g}$ was put in $300 \mathrm{ml}$ of boiling water for 5 minutes and stir to make sugar syrup of $50{ }^{\circ}$ Brix concentration. Sugar syrup was filtered through muslin cloth to remove the impurities present in it. The total solid of sugar syrup was determined by using an ERMA (Japan) make hand refractrometer having range $32-60{ }^{\circ}$ Brix.

\section{Dipping Gulabjamuns in Syrup}

The fried Gulabjamun balls were dipped in sugar syrup containing $50{ }^{\circ}$ Brix TSS for 4 hours at $70^{\circ} \mathrm{C}$ temperature (Rangi et al., 1985; Singh et. al., 2009) and samples were taken out from the syrup before packing.

\section{Packaging for Storage}

Gulabjamun samples were packed in paperboard boxes of $500 \mathrm{~g}$ capacity with butter paper and these were stored at ambient $\left(26.60^{\circ} \mathrm{C}\right.$ to $\left.36.25^{\circ} \mathrm{C}\right)$ and refrigerated (about 4 to $7^{\circ} \mathrm{C}$ temperature using domestic refrigerator) conditions in the months of June and July 2005. The packed and stored Gulabjamuns samples were randomly taken out for quality 
analysis at every alternative day interval until samples found unsuitable for consumption during storage studies.

\section{Protein Content}

Protein content of Gulabjamun samples was estimated using Microkjeldahl distillation apparatus as per the method of AOAC, (2002).

$$
\begin{gathered}
\text { Nitrogen, } \mathrm{N}_{2}(\%)=\frac{\text { Titer value } \times 0.0014 \times \text { volume made } \times 100}{\text { Aliques taken } \times \text { weight of the sample }(\mathrm{g})} \\
\mathrm{N}_{2}(\%)=\frac{\mathrm{A} \times 0.0014 \times 250 \times 100}{(5 \times 1)} \\
\therefore \text { Protein }(\%)=\mathrm{N}_{2}(\%) \times 6.25
\end{gathered}
$$

\section{Fat Content}

Crude fat content (triglycerides of fatty acid) of Gulabjamuns samples were estimated as per the standard method of AOAC, (2002) using fat extraction tube of soxhlet apparatus.

\section{Sensory Evaluation}

$$
\text { Fat content, } \%=\frac{\text { Amount of ether extract, } g}{\text { Weight of the sample, } g} \times 100
$$

Stored Gulabjamuns were evaluated for overall acceptability of samples by a randomly selected panel. The panel was asked to evaluate for appearance, color, texture, flavour and overall acceptability as per 9 point Hedonic scale (Rangi et al., 1985).

\section{Textural Behaviour}

Textural profile analysis (TPA) of Gulabjamuns was carried out using texture analyzer (TA-Hdi) in the Engineering Properties Laboratory of the department. The texture behaviour of whole Gulabjamuns was estimated in terms of the TPA curve. The parameters of the brittleness, hardness, cohesiveness, chewiness, springiness and gumminess were calculated from the plot of two cyclic compression tests. The following textural parameters were estimated as follows (Bourne, 1982):

Hardness: The maximum height of curve during the first compression.

Brittleness: Height of first significant break of multi peak shape of first chew.

Cohesiveness: Ratio of area under second peak to that of first peak i.e. $\mathrm{A}_{2} / \mathrm{A}_{1}$.

Elasticity: Test speed $\times$ distance on $\times$ axis from start of second bite to its peak.

Chewiness: Hardness $\times$ cohesiveness $\times$ elasticity.

Gumminess: Hardness $\times$ cohesiveness.

\section{Statistical Analysis}

The statistical analysis was carried out using two ways ANOVA in General Linear Model (GLM) using Statistical Package for Social Sciences (SPSS) version 7.5. Means were computed and tested at 5\% levels of significant to arrive the best results of the treatments (Little et al., 1991).

\section{Results and Discussion}

The fried Gulabjamun balls were dipped in sugar syrup containing $50^{\circ}$ Brix TSS for 4 hours at $70^{\circ} \mathrm{C}$ temperature (Rangi et al., 1985; Singh et. al., 2009) and samples were taken out from the syrup having moisture content of $24.15 \%$ (w.b.). An acidity level was within the standard limit of CODEX and samples of Gulabjamun were free from pathogens, coliforms as per microbial studies (Anonymous, 2003). Essential amino acid increased with increase in the soy flour fortification.

\section{Effect of storage on Protein content}

Different levels of soy flour mixed Gulabjamuns were packed in paperboard boxes of $500 \mathrm{~g}$ capacities and stored at ambient condition and refrigerated temperature $\left(5^{\circ} \mathrm{C}\right.$ in domestic refrigerator) to study the effect of Gulabjamun storability on protein content (Table 1). It was observed that protein content of Gulabjamuns decreased with increase in the storage periods in all levels of soy flour mix Gulabjamuns. The loss in protein content was attributed to the fact that protein chains form loose mesh, which holds water with in network. With loss in moisture content, they become disorganized and soluble nutrients are carried out (Cox, 1979). Also the reaction between sugars and amino acids leads to break down of protein molecules (Bennion, 1980). The protein content of ambient stored control sample (T1) decreased from $14.05 \%$ to $10.75 \%$ in 8 days of storage period with 0.368 at $5 \%$ critical difference (CD) and $1.67 \%$ critical variance (CV). Maximum and minimum protein loss was observed in T3 (6.66\% soy flour was supplemented to replace wheat flour) and T2 (3.33\% soy flour was supplemented to replace wheat flour) samples of Gulabjamun samples at the end of storage period, respectively (Table 1).

The protein content of control sample of refrigerated storage decreased from $14.05 \%$ to $10.15 \%$ in 8 days of storage period with 0.1583 at $5 \% \mathrm{CD}$ and $0.74 \% \mathrm{CV}$. Maximum protein loss of $27.75 \%$ was observed in control sample (T1) and minimum loss of protein in soy flour supplemented Gulabjamun samples at the end of 10 days storage period (Table 1). Protein loss was increased to $30.93 \%$ in T4 samples of gulabjamun after 14 days of storage period. It is clear that there is a significant effect of storage conditions on the protein content of Gulabjamuns at all levels of soy flour.

\section{Effect of storage on Fat content}

From Table 2, it's clear that the fat content of Gulabjamuns decreased with the increase in storage period at both ambient conditions and refrigeration conditions irrespective of the soy flour mix in Gulabjamun. The decrease in fat content of Gulabjamun might be due to the oxidation of fat and breakdown of triglycerides to free fatty acids with passage of time. The fat content of Gulabjamuns were non-significantly different from each in ambient condition and found decreased in fat content in all levels of soy flour mix Gulabjamuns irrespective of soy flour supplement concentration where as fat content of Gulabjamuns were significantly different from each other in refrigeration storage. All ambient stored Gulabjamun samples were lost about $31 \%$ of fat in 8 days as compare to freshly prepared Gulabjamun samples. Maximum and minimum critical differences at $5 \%$ were 0.3902 and 0.1314 in $\mathrm{T} 2$ and $\mathrm{T} 3$ samples Gulabjamuns with $1.64 \%$ and $0.61 \% \mathrm{CV}$, respectively. 
However, control samples of refrigerated storage were lost maximum of $36.21 \%$ fat and $\mathrm{T} 2$ sample lost minimum of $19.27 \%$ fat in 10 days as compare to freshly prepared $G u$ labjamun samples. A significant effect of storage conditions on the fat content of Gulabjamuns at all levels of soy flour was observed.

\section{Effect of storage on Textural behaviour of Gulabjamuns}

Textural characteristics of fresh and soy flour supplemented Gulabjamuns stored at ambient conditions were presented in Fig. 1 and 2. The hardness, cohesiveness, chewiness and gumminess values of fresh control sample of Gulabjamuns were $203.132 \mathrm{~g}, 0.45 \mathrm{~g}, 356.50 \mathrm{~g}$ and $91.4 \mathrm{~g}$ where increased to $723.82 \mathrm{~g}, 0.63 \mathrm{~g}, 1368.02 \mathrm{~g}$ and $456.06 \mathrm{~g}$ after 8 days of ambient storage, respectively. Textural characteristics of fresh and soy fortified Gulabjamuns stored at refrigeration conditions have been given in Fig 3 and 4. Percentage change of hardness between the fresh and refrigerated stored Gulabjamun were $80.27 \%, 76.79 \%$, $73.09 \%$ and $67.92 \%$ in $\mathrm{T} 1, \mathrm{~T} 2, \mathrm{~T} 3$ and $\mathrm{T} 4$ samples, where as chewiness was $80.70 \%, 77.95 \%, 67.58 \%$ and $62.35 \%$, respectively. Similarly, gumminess $(87.13 \%, 82.59 \%, 78.39 \%$ and $70.96 \%)$ and cohesiveness $(34.78 \%, 25 \%, 19.7 \%$ and $9.46 \%$ ) were decreased in terms of percentage with increase in soy flour supplementation level except elasticity.

From these figures it's clear that the hardness (g), cohesiveness $(\mathrm{g})$, chewiness $(\mathrm{g})$ and gumminess $(\mathrm{g})$ of the $\mathrm{Gu}$ labjamuns were increased with the increase in the soy flour concentration level and significantly increases with increase in storage period and decrease in elasticity $(\mathrm{mm})$ with increase in mix concentration and storage period. This increase might be due to the increase in protein content, decrease in fat content and reduction in moisture content (Gulhati et al., 1992). It was found that chewing energy required during mastication increased with the increase in storage periods.

\section{Overall acceptability of Gulabjamuns during storage}

Overall acceptability was the average of appearance, colour, texture and flavour. Overall acceptability was the highest in T3 soy flour supplemented Gulabjamuns and it was found that the overall acceptability decreased with increase in storage period in both storage conditions. Storage conditions had the significant effect $(\mathrm{p}<0.05)$ on the overall acceptability of T2 and T3 samples of Gulabjamuns and no significant effect on $\mathrm{T} 1$ and $\mathrm{T} 4$ samples and had a significant effect on T2 and T3 samples. At ambient condition, overall acceptability score was decreased from 8.75 to 1.5 in control sample (after 8 days of storage), from 8.8 to 2.25 in T2 samples (after 10 days of storage), 8.9 to 1.75 in T3 samples (after 12 days of storage), and 8.75 to 3.25 in T4 samples of Gulabjamuns (after 12 days of storage). Overall acceptability score decreased from 8.63 to 2.25 in T1 sample, 8.80 to 2.25 in T2 sample, 8.85 to 3.25 in T3 samples and 8.63 to 3.50 in T4 samples of Gulabjamuns stored in refrigeration conditions.

\section{Shelf life of Gulabjamuns}

The shelf life of T1, T2 and T4 samples of Gulabjamuns was 8 days and T3 samples for 10 days at ambient condition.
In refrigeration storage the shelf life was enhanced to 10 days in T1 and T2 samples of Gulabjamuns whereas 12 and 14 days for T3, and T4 samples, respectively. Maximum storability was observed in refrigeration storage as compare with the ambient storage. It may be due to the higher temperature and low relative humidity during ambient storage studies in the months of June and July 2005. The average maximum and minimum temperature were $39.3^{\circ} \mathrm{C}$ and $26.5^{\circ} \mathrm{C}$ in June month with $49 \% \mathrm{RH}$ where as $33.2^{\circ} \mathrm{C}$ and $26.7^{\circ} \mathrm{C}$ temperature with $79 \% \mathrm{RH}$ in the month of July. It is clear from the data that the shelf life of Gulabjamuns increased with increase in soy flour levels.

\section{Comparison between Soy flour mix and commercial Gulabjamuns}

Freshly prepared commercial Gulabjamun samples were procured from the two popular sweet shops of the market and analysed for quality to compare with the soy fortified Gulabjamuns. Initial protein content of T3 was $18.01 \%$ and decreased to $12.54 \%$ in 10 days of storage period whereas the protein contents of commercial samples were $9.75 \%$ and $13.25 \%$, which decreased to $8.12 \%$ and $11.67 \%$ respectively in 6 days of storage at ambient condition (Table 1). The fat content of $\mathrm{T} 3$ samples was $15.01 \%$ and decreased to $9.84 \%$ in 10 days of storage period where as the fat contents of commercial samples (Table 2) were $10.28 \%$ and $9.23 \%$ which has decreased to $6.81 \%$ and $6.85 \%$ respectively after 6 days of storage at ambient conditions (temperature varied from $25^{\circ} \mathrm{C}$ to $33^{\circ} \mathrm{C}$ and relative humidity varied from $73 \%$ to $99 \%$ ). Its clear that shelf life of soy-fortified Gulabjamun is more then the commercially available Gulabjamun samples at ambient storage condition and significantly different from each other.

At refrigerated conditions, protein content of $\mathrm{T} 3$ samples decreased from $18.01 \%$ to $14.55 \%$ in 10 days of storage period (Table 1), whereas it was decreased from $9.75 \%$ to $8.12 \%$ and $13.25 \%$ to $12.6 \%$ in 6 days of storage period in commercial samples 1 and 2, respectively (Table 1). Fat content of T3 Gulabjamun samples was decreased from $15.01 \%$ to $11.10 \%$ in 10 days of refrigerated storage and commercial samples 1 and 2 were decreased from $10.28 \%$ to $6.95 \%$ and $9.23 \%$ to $6.8 \%$ in 6 days of storage period, respectively (Table 2 ).

Pair wise comparisons of protein and fat content of $G u$ labjamuns stored at ambient and refrigerated conditions with different soy flour mix concentration and storage period have been done statistically. It has concluded that there was significant difference of storage conditions on the protein content and significant difference $(\mathrm{p}<0.05)$ between the protein content of different types of soy flour mix samples except control (T1) and commercial sample 2. There was significant effect of storage period on the protein content of Gulabjamuns at all levels of soy flour mix samples. There is no significant $(p<0.05)$ effect of storage conditions on the reduction of fat content of Gulabjamuns and significant difference $(p<0.05)$ between the fat content of different concentration levels of soy flour mix except $\mathrm{T} 2$ and $\mathrm{T} 3$ samples and both commercial sample. There was significant 
effect of days of storage period on the fat content of Gulabjamuns at all levels of soy flour. The rate of fat content de-

crease was higher at ambient conditions than refrigerated condition.

Table 1. Effect of storage conditions on protein content (\%) of soy fortified and commercial samples of Gulabjamuns

\begin{tabular}{|c|c|c|c|c|c|c|c|c|c|c|c|c|}
\hline \multirow{4}{*}{$\begin{array}{c}\text { Samples } \\
\begin{array}{c}\text { Storage } \\
\text { period } \\
\text { (days) }\end{array}\end{array}$} & \multicolumn{12}{|c|}{ Protein content (\%) } \\
\hline & \multicolumn{8}{|c|}{ Soy fortified Gulabjamun samples } & \multicolumn{4}{|c|}{ Commercial Gulabjamun Samples } \\
\hline & \multicolumn{4}{|c|}{$\begin{array}{l}\text { Ambient storage } \\
\text { condition }\end{array}$} & \multicolumn{4}{|c|}{$\begin{array}{c}\text { Refrigerated storage } \\
\text { condition }\end{array}$} & \multicolumn{2}{|c|}{$\begin{array}{l}\text { Ambient storage } \\
\text { condition }\end{array}$} & \multicolumn{2}{|c|}{$\begin{array}{l}\text { Refrigerator storage } \\
\text { condition }\end{array}$} \\
\hline & $\mathrm{T} 1$ & $\mathrm{~T} 2$ & $\mathrm{~T} 3$ & $\mathrm{~T} 4$ & $\mathrm{~T} 1$ & $\mathrm{~T} 2$ & T3 & $\mathrm{T} 4$ & Sample 1 & Sample 2 & Sample 1 & Sample 2 \\
\hline 0 & 14.05 & 14.81 & 18.01 & 19.56 & 14.05 & 14.81 & 18.01 & 19.56 & 9.75 & 13.25 & 9.75 & 13.25 \\
\hline 2 & 12.63 & 13.12 & 17.08 & 18.01 & 13.55 & 14.6 & 17.9 & 19.45 & 9.68 & 13.60 & 9.63 & 13.16 \\
\hline 4 & 11.98 & 13.02 & 15.54 & 17.08 & 12.73 & 13.6 & 17.06 & 18.51 & 9.25 & 12.60 & 9.13 & 13.06 \\
\hline 6 & 11.24 & 12.40 & 14.46 & 16.04 & 11.66 & 12.83 & 16.65 & 17.89 & - & - & 8.81 & 12.90 \\
\hline 8 & 10.75 & 12.10 & 13.18 & 15.65 & 10.45 & 12.01 & 15.01 & 16.8 & - & - & 8.48 & 12.60 \\
\hline 10 & - & - & 12.54 & - & 10.15 & 11.85 & 14.55 & 15.75 & - & - & 8.12 & - \\
\hline 12 & - & - & - & - & - & - & 13.83 & 14.92 & - & - & - & - \\
\hline 14 & - & - & - & - & - & - & - & 13.51 & - & - & - & - \\
\hline $\mathrm{CD}_{0.05}$ & 0.3680 & 0.6106 & 0.6361 & 0.1817 & 0.1583 & 0.4362 & 0.4941 & 0.1299 & - & - & - & - \\
\hline CV (\%) & 1.67 & 2.57 & 2.36 & 0.56 & 0.74 & 1.85 & 1.75 & 0.44 & - & - & - & - \\
\hline
\end{tabular}

Spoiled or unfit for consumption

Table 2. Effect of storage conditions on fat content (\%) of soy fortified and commercial samples of Gulabjamuns

\begin{tabular}{|c|c|c|c|c|c|c|c|c|c|c|c|c|}
\hline \multirow{4}{*}{$\begin{array}{c}\text { Samples } \\
\text { Storage } \\
\text { period } \\
\text { (days) }\end{array}$} & \multicolumn{12}{|c|}{ Fat content $(\%)$} \\
\hline & \multicolumn{8}{|c|}{ Soy fortified Gulabjamun samples } & \multicolumn{4}{|c|}{ Commercial Gulabjamun Samples } \\
\hline & \multicolumn{4}{|c|}{$\begin{array}{l}\text { Ambient storage } \\
\text { condition }\end{array}$} & \multicolumn{4}{|c|}{$\begin{array}{c}\text { Refrigerated storage } \\
\text { condition }\end{array}$} & \multicolumn{2}{|c|}{$\begin{array}{c}\text { Ambient storage } \\
\text { condition } \\
\end{array}$} & \multicolumn{2}{|c|}{$\begin{array}{c}\text { Refrigerator storage } \\
\text { condition } \\
\end{array}$} \\
\hline & $\mathrm{T} 1$ & $\mathrm{~T} 2$ & $\mathrm{~T} 3$ & $\mathrm{~T} 4$ & $\mathrm{~T} 1$ & $\mathrm{~T} 2$ & $\mathrm{~T} 3$ & $\mathrm{~T} 4$ & Sample 1 & Sample 2 & Sample 1 & Sample 2 \\
\hline 0 & 22.12 & 15.25 & 15.01 & 13.86 & 22.12 & 15.25 & 15.01 & 13.86 & 10.28 & 9.03 & 10.28 & 9.03 \\
\hline 2 & 18.65 & 14.61 & 13.41 & 12.50 & 18.77 & 14.89 & 13.52 & 12.43 & 9.91 & 8.83 & 9.82 & 8.92 \\
\hline 4 & 17.54 & 13.54 & 12.90 & 11.90 & 17.68 & 13.91 & 12.70 & 12.01 & 8.62 & 7.64 & 8.81 & 7.78 \\
\hline 6 & 16.62 & 11.72 & 10.83 & 10.05 & 16.72 & 13.42 & 12.20 & 11.56 & & & 8.45 & 7.36 \\
\hline 8 & 15.10 & 10.41 & 10.10 & 9.56 & 15.23 & 12.87 & 11.64 & 11.02 & & & 7.12 & 6.81 \\
\hline 10 & - & - & 9.84 & - & 14.11 & 12.31 & 11.10 & 10.67 & & & 6.95 & - \\
\hline 12 & - & - & - & - & - & - & 10.54 & 10.14 & - & - & - & - \\
\hline 14 & - & - & - & - & - & - & - & 9.61 & - & - & - & - \\
\hline $\mathrm{CD}_{0.05}$ & 0.2695 & 0.3902 & 0.1314 & 0.2818 & 0.2479 & 0.3537 & 0.1199 & 0.2523 & - & - & - & - \\
\hline CV (\%) & 0.79 & 1.64 & 0.61 & 1.34 & 0.80 & 1.44 & 0.55 & 1.28 & - & - & - & - \\
\hline
\end{tabular}

Spoiled or unfit for consumption

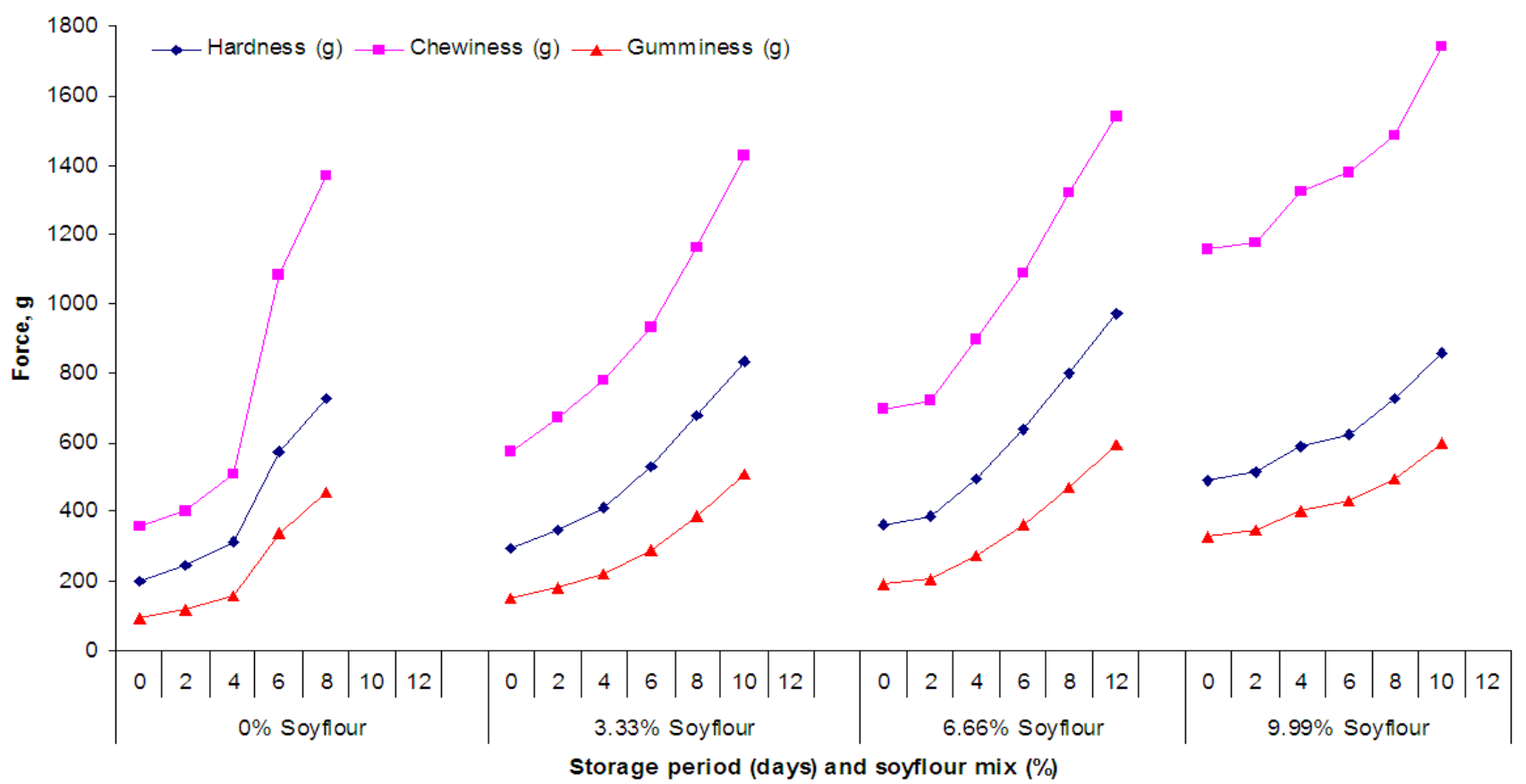

Figure 1. TPA of Gulabjamun stored at ambient condition 


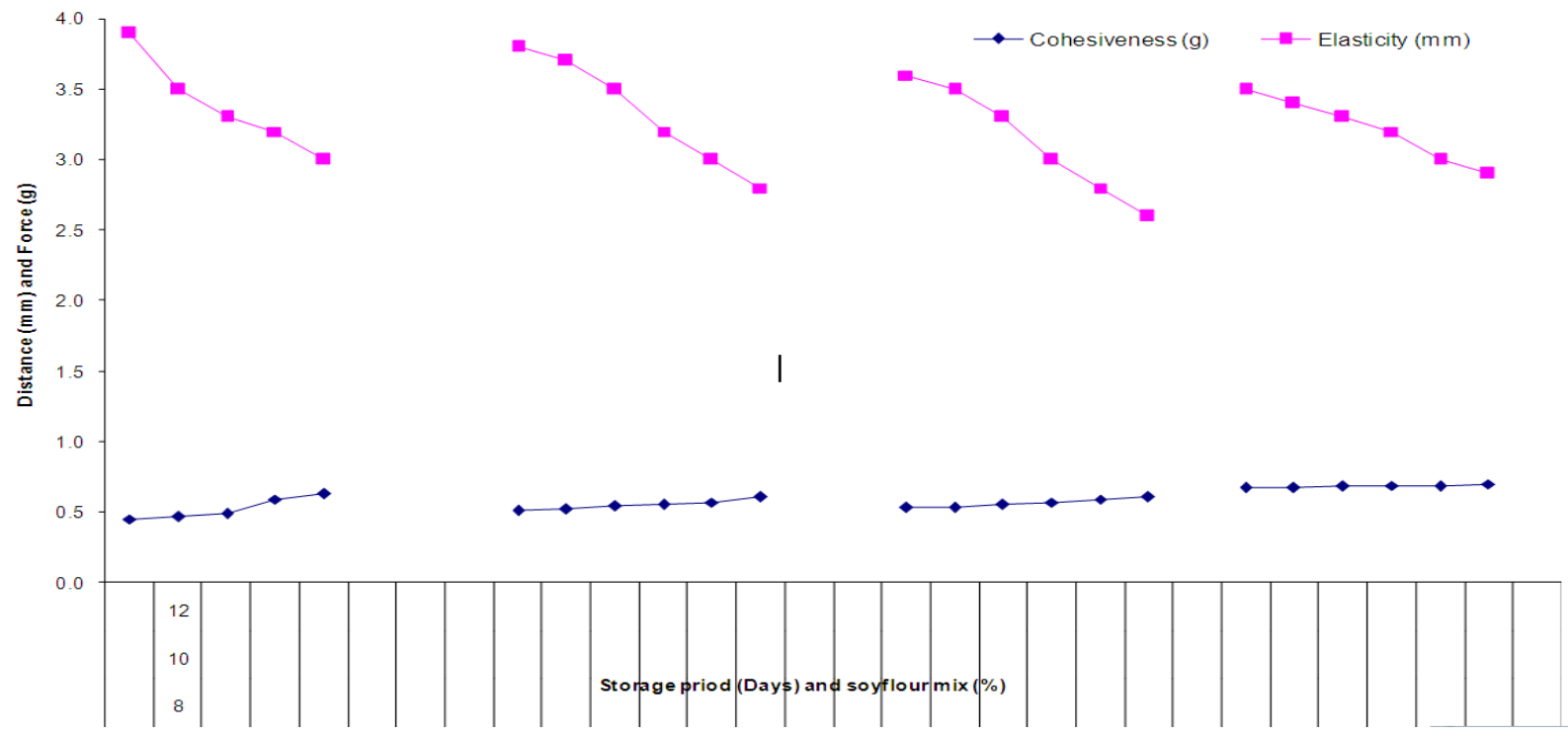

Figure 2. Cohesiveness and elasticity of Gulabjamun stored at ambient condition

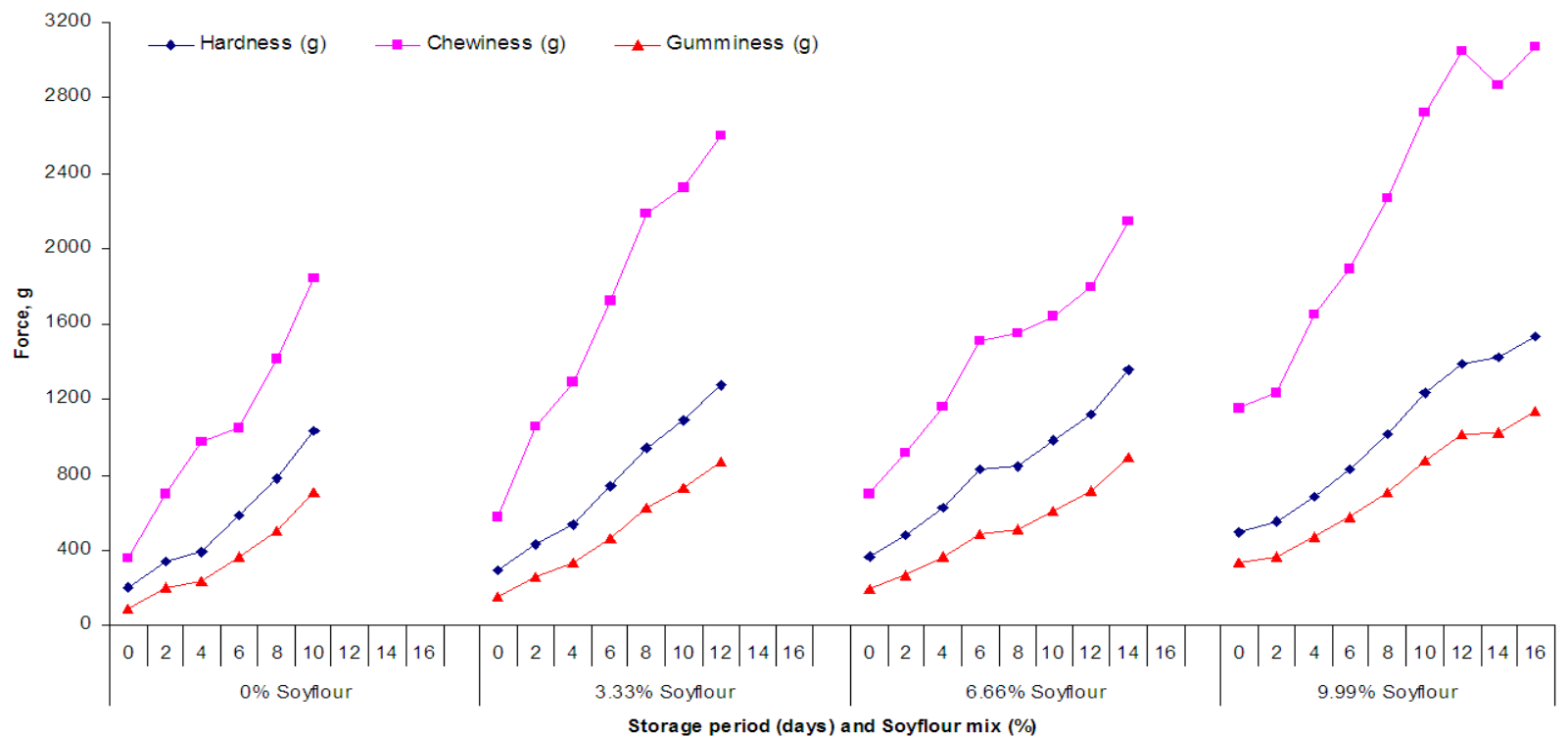

Figure 3. TPA of Gulabjamun stored at refrigerated condition

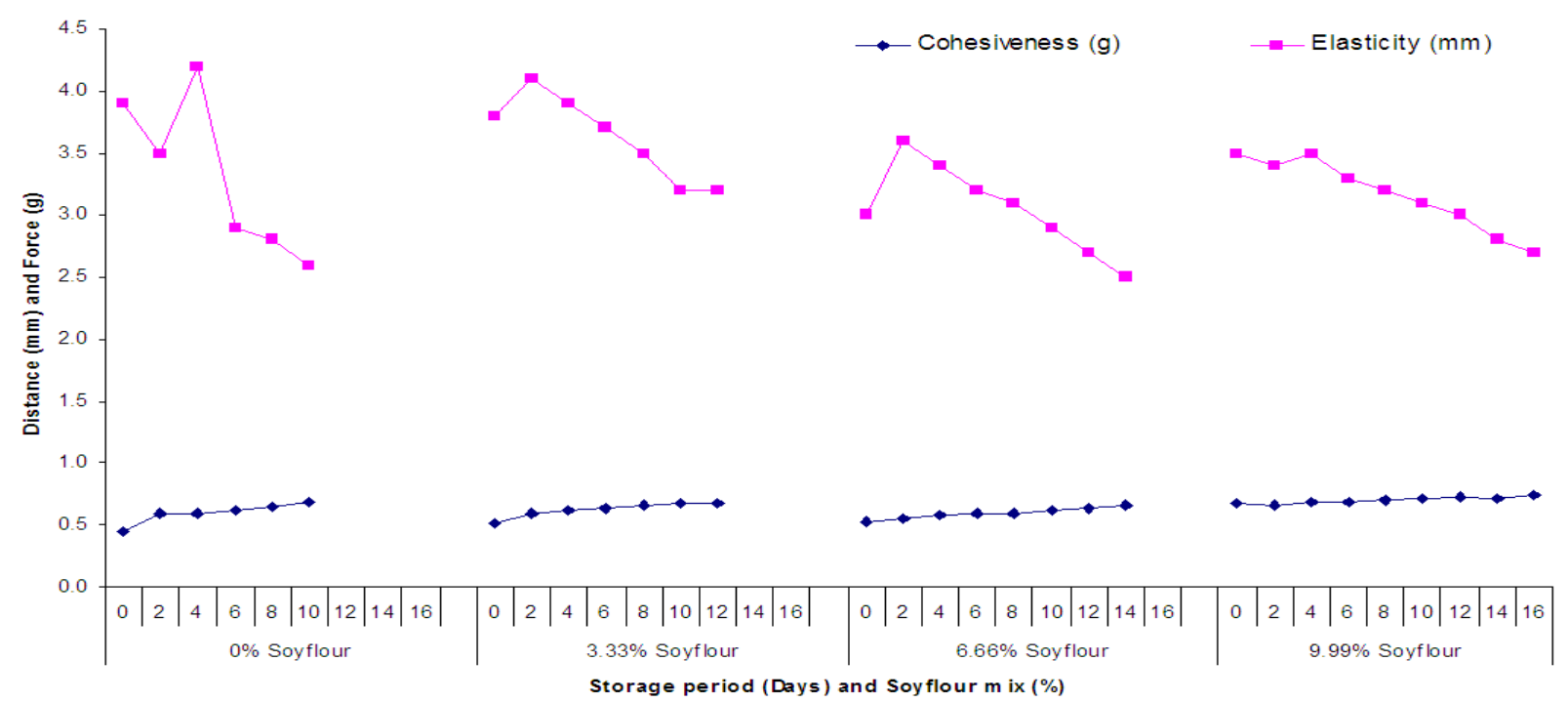

Figure 4. Effect of refrigerated storage on cohesiveness and elasticity of Gulabjamun 


\section{Conclusions}

Physico-chemical properties such as protein and fat content and sensory attributes of Gulabjamuns are crucial. Protein and fat content of Gulabjamuns decreased with increase in the storage periods irrespective of soy flour concentration level mix in the Gulabjamuns and storage condition. The hardness (g), cohesiveness (g), chewiness (g) and gumminess (g) of the stored Gulabjamuns (both conditions) were increased with the increase in the soy flour concentration in soy flour supplemented Gulabjamuns and significantly increase with increase in storage period in both soy flour supplemented and commercial samples. The shelf life of $G u$ labjamuns at ambient condition varied from 8 to 10 days and 10 to 14 days in refrigeration where as commercial samples could lost only for 4 to 8 days. Hence, soy flour supplementation of about $6.66 \%$ in the Gulabjamuns will increase the nutritional quality as well as storability of $\mathrm{Gu}$ labjamuns.

\section{REFERENCES}

[1] ACHI, O. K. (1999). Quality attributes of fermented yam flour supplemented with processed soy flour. Plant Foods Hum Nutr. 54 (2): 151-158

[2] ADDO, K., LYKINS, S. and COTTON, C. (1996). Indigenous fermentation and soy fortification: effects on protein quality and carbohydrate digestibility of a traditional Ghanaian corn meal. Food Chemistry. 57 (3): 377-380, doi: 10.1016/0308-8146(95)00232-4

[3] ANNAN, N. T., PLAHAR, W. A., POLL, L. and JAKOBSEN, M. (2005). Effect of soybean fortification on Ghanaian fermented maize dough aroma. International Journal of Food Science and Nutrition. 56 (5): 315-326

[4] ANONYMOUS. 2003. Codex alimentation commission, Joint FAO/ WHO food standards progreamme, 35th session of CCFAC, Arusha, Tanzania, $17-21$ March 2003. www.codexindia.nic.in/shadowcommittees/ccfac/35indview. pdf

[5] AOAC (2002). Method for cereal fat. Introduction to the Chemical Analysis of foods. pp 186

[6] AOAC (2002). Method for microkjeldahl method. Introduction to the Chemical Analysis of foods. pp 210-211

[7] BENNION, M. (1980). Science of Food Harper and Row, San Francisco, pp 149
[8] BOURNE, M. (1982). Food texture and viscosity: concept and measurement, Academic Press. Inc. New York, pp $114-117$

[9] COX, P. M. (1979). Deep-freezing a comprehensive guide to its theory and practice, Faber and Faber, London

[10] GULHATI, H.B., RATHI, S.D., SYED, H.H. and BACHE, C.S. (1992). Studies on Qualities of Gulabjamun. Indian Food Packer. 46 (6): 43-46

[11] LITTLE, R. C., FREUND, R. J. and SECTOR, P. C. (1991). SAS system for Linear Models. SAS Institute Inc., Cary

[12] MISHRA, H. N. and MUKHERJEE, R. K. (1992). Storage stability of full fat soy flour and soy wheat flour blend. Journal of Food Science and Technology. 29 (4): 224-227

[13] NATIONAL SOYBEAN RESEARCH LABORATORY (2008). National Soybean Research Laboratory, USA, http://www.nsrl.uiuc.edu/aboutsoy/soynutrition.html

[14] PLAHAR, W.A., NTI, L.A., and ANNAN, N.T. (1997). Effect of soy-fortification method on fermentation characteristics and nutritional quality of fermented maize meal. Plant Foods for Human Nutrition. 51(4): 365-380

[15] RAHMAN, M. S. and PERERA, C. O. (1999). Drying and food preservation. In: Handbook of Food Preservation by M. Shafier Rahman (ed.). Marcel Dekker, Inc. New York, Basel. pp 173-216

[16] RANGI, A.S., MINHAS, K.H. and SIDHU, J.S. (1985). Indigenous Milk products I standardization of recipe for $\mathrm{Gu}-$ labjamun. Journal of Food Science and Technology. 22: 191-193

[17] SAXENA, S., RAMACHANDRAN, LATA, SINGH, S. and SHARMA, R.S. (1996). Preparation and chemical quality of Gulabjamun premixes and sensory quality of ready to serve gulab jamuns made from soya flour and milk solids. Indian Food Packer. 50 (2): 41-52

[18] SINGH, N., CHAUHAN, G. S. and BAINS, G. S. (1989). Effect of soy flour supplementation on the quality of cooked noodles. International Journal of Food Science and Technology, 24 (1): 111-114

[19] SINGH, A. K., KADAM, D. M., SEXENA, M. and SINGH, R. P. (2009). Efficacy of Defatted Soy flour Supplement in Gulabjamun. African Journal of Biochemistry Research. 3 (4); 130-135

[20] WADUD, S., ABID, H., ARA, H., KOSAR, S. and SHAH, W. H. (2004). Production, quality evaluation and storage stability of vegetable protein-based baby foods. Food Chemistry. 85 (2): 175-179, doi:10.1016/S0308-8146(02)0 0516-2 